\title{
Diallyl disulfide inhibits the metastasis of type II esophageal-gastric junction adenocarcinoma cells via NF-kB and PI3K/AKT signaling pathways in vitro
}

\author{
XIAORAN YIN ${ }^{1}$, CHENG FENG $^{2}$, LILI HAN ${ }^{1}$, YINAN MA ${ }^{1}$, YANG JIAO ${ }^{3}$, JUN WANG ${ }^{4}$, \\ LIJUN JIA ${ }^{1}$, FUCHUN JING ${ }^{5}$, XIAOYAN GAO ${ }^{1}$, YINBIN ZHANG ${ }^{1}$ and JUN ZHANG $^{2}$
}

Departments of ${ }^{1}$ Oncology, ${ }^{2}$ Digestion, ${ }^{3}$ Endocrinology, The Second Affiliated Hospital of Xi'an Jiaotong University,
Xi'an, Shaanxi $710004 ;{ }^{4}$ Department of Gastroenterology, Xi'an Hospital of Traditional Chinese Medicine, Xi'an,
Shaanxi 710021; ${ }^{5}$ Department of Digestive Diseases, Baoji People's Hospital, Baoji, Shaanxi 721000, P.R. China

Received June 3, 2017; Accepted November 14, 2017

DOI: 10.3892/or.2017.6113

\begin{abstract}
Esophageal-gastric junction adenocarcinoma (AEG) is an aggressive tumor with high incidence and dismal prognosis worldwide. Despite significant advances in therapeutic strategies, the 5-year survival rate still remains low. Diallyl disulfide (DADS), which is one of the major volatile components isolated from garlic, has been shown to have multi-targeted antitumor activities in a variety of cancer cells. However, the exact anti-metastatic effects and underlying molecular mechanisms of DADS in AEG have not been elucidated. The present study demonstrated that DADS inhibited cell viability of OE19 cells with low cytotoxicity to healthy hepatocytes, L02 cells, in vitro. Non-toxic doses of DADS were $\leq 10 \mu \mathrm{g} / \mathrm{ml}$ for a $24-\mathrm{h}$ treatment. Our data showed that these non-toxic doses of DADS were found to block the metastasis of OE19 cells by suppressing MMPs, increasing u-PA and TIMPs, as well as altering the balance of MMPs/ TIMPs, which at least in part resulted from the suppression of NF- $\kappa \mathrm{B}$ and PI3K/AKT signaling pathways. The present study provides a previously neglected insight into the investigation of DADS in suppressing tumor metastasis and its underlying molecular mechanisms in vitro. Hence, DADS could be a promising anticancer agent for anti-metastatic treatment of AEG in the future.
\end{abstract}

Correspondence to: Professor Xiaoran Yin, Department of Oncology, The Second Hospital of Xi'an Jiaotong University, 157 Xiwu Road, Xi'an, Shaanxi 710004, P.R. China

E-mail: yinxiaoran@163.com

Professor Jun Zhang, Department of Digestion, The Second Affiliated Hospital of the School of Medicine, Xi'an Jiaotong University, 157 Xi Wu Road, Xi'an, Shaanxi 710004, P.R. China

E-mail: jun_3z@163.com

Key words: esophageal-gastric junction adenocarcinoma, diallyl disulfide, metastasis, NF- $\mathrm{BB}, \mathrm{PI} 3 \mathrm{~K} / \mathrm{AKT}$

\section{Introduction}

Esophageal-gastric junction adenocarcinoma (AEG) is different from either esophageal cancer or gastric carcinoma in pathology and the clinic, which have their center within $5.0 \mathrm{~cm}$ proximal or distal from the cardia (1). According to Siewert's classification, AEG is currently divided into three types in terms of the anatomic location of the tumor center. Type I termed as distal esophageal carcinoma usually originates from Barrett's esophagus. Type II termed as true carcinoma of the cardia originates from the cardial epithelium or short segments of intestinal metaplasia in the esophagogastric transition. Type III termed as sub-cardial gastric carcinoma originates from short segments of the intestinal metaplasia (2).

Metastasis is the spread of cancer cells from the primary site to form tumors at distant sites. Tumors with invasive and metastatic potential are relatively resistant to chemotherapy. Therefore, metastasis is responsible for more than $90 \%$ of cancer mortality (3). Moreover, traditional chemotherapeutic agents and radiotherapy for cancer management often have obvious toxicity. Thus, it is important to develop natural and safer compounds as therapeutic agents to reduce the risk and to overcome various types of carcinomas (4). Some of these natural sources have been characterized as potential agents with anti-metastatic activity. Garlic, a member of the Liliaceae family used for seasoning food in many different countries, is considered to exhibit medicinal properties in various diseases such as cardiovascular disease and diabetes, infections as well as different types of cancers (5).

In the present study, we focused on diallyl disulfide (DADS), a major lipid-soluble organic compound isolated from crushed garlic which represents $40-60 \%$ of garlic essential oil (6). DADS has a wide variety of biological activities, such as stimulating the immune system, reducing the risk of cardiovascular disease and diabetes, protecting against infections, and show significant chemopreventive and antitumor activities (7-9). However, the impacts and molecular mechanisms underlying potential anti-metastasis activities of DADS in human type II AEG cells are not yet well understood. 
Thus, the aim of the present study was to demonstrate the anti-metastatic functions of DADS and the underlying mechanisms in human type II AEG OE19 cells. We demonstrated that DADS inhibited the cell viability of OE19 cells with low cytotoxicity to healthy L02 hepatocytes. Non-toxic doses of DADS were $\leq 10 \mu \mathrm{g} / \mathrm{ml}$ after 24 -h treatment. Furthermore, the results from the present study revealed that these non-toxic doses of DADS blocked the migration and invasion of OE19 cells by suppressing MMPs, increasing u-PA and TIMPs, as well as altering the balance of MMPs/TIMPs, which at least in part results from the suppression of $\mathrm{NF}-\kappa \mathrm{B}$ and PI3K/AKT signaling pathways. This study presented new evidence of the role of DADS in type II AEG treatment and specifically in the metastatic progression of OE19 cells.

\section{Materials and methods}

Materials. DADS was purchased from Sigma-Aldrich (St. Louis, MO, USA). The MMP-2 and MMP-9 gelatin zymography standard was acquired from Chemicon International (Temecula, CA, USA). Primary antibodies against MMP-2 rabbit antibody (\#4022), MMP-9 rabbit antibody (\#3852), TIMP-1 rabbit antibody (\#8946), TIMP-2 rabbit antibody (\#5738), PI3K rabbit antibody (\#4252), p-PI3K rabbit antibody (\#4228), AKT rabbit antibody (\#75692) and p-AKT rabbit antibody (\#13461) were purchased from Cell Signaling Technology (Beverly, MA, USA). Primary antibodies against u-PA mouse antibody (sc-59729), NF-кB (p65) mouse antibody (sc-71675), I $\kappa \mathrm{B} \alpha$ mouse antibody (sc-52900), $\mathrm{p}-\mathrm{I} \kappa \mathrm{B} \alpha$ mouse antibody (sc-52943) and $\beta$-actin mouse antibody (sc-47778), as well as HRP-conjugated goat anti-mouse and anti-rabbit secondary antibodies were obtained from Santa Cruz Biotechnology (Santa Cruz, CA, USA).

Cell culture. Human type II AEG cell line, OE19, was established in 1993 from a gastric cardia adenocarcinoma (AEG, type II) of a 72-year-old male patient. The tumor was identified as pathological stage III (UICC) and showed moderate differentiation. It was a gift from the Gastroenterology Department of Southwest Hospital of the Third Military Medical University. Human normal liver cell line L02 was obtained from the Chinese Academy of Shanghai Institute of Cell Biology (Shanghai, China). These cells were routinely cultured in RPMI-1640 medium supplemented with $10 \%$ heat-inactivated fetal bovine serum (FBS; Gibco, Life Technologies, Vienna, Austria), $100 \mathrm{U} / \mathrm{ml}$ penicillin and $100 \mathrm{mg} / \mathrm{l}$ streptomycin, and were maintained at $37^{\circ} \mathrm{C}$, in a humidified incubator containing $5 \% \mathrm{CO}_{2}$. Cells in a logarithmic growth phase were used for the assays (10).

Cell viability assay. The cell viability was assessed by MTT reduction assay (11). DADS was dissolved in phosphatebuffered saline (PBS) and prepared at the concentration of $1000 \mu \mathrm{g} / \mathrm{ml}$ as stock solution. DADS was further diluted to the appropriate concentrations before use.

OE19 cells and L02 cells ( $2 \times 10^{4}$ cells/well) were seeded in 96-well plates. After $24 \mathrm{~h}$ of attachment, various concentrations of DADS were applied to the cells and the incubation was extended. PBS was used as control. After the treatment, the cells were washed with PBS, and $20 \mu \mathrm{l}$ of MTT solution
( $5 \mathrm{mg} / \mathrm{ml})$ was added to each well for an additional incubation for $4 \mathrm{~h}$ at $37^{\circ} \mathrm{C}$ in the dark. The solution was discarded and the blue crystals were dissolved with $150 \mu$ l dimethyl sulfoxide (DMSO). The optical density was measured at $570 \mathrm{~nm}$ (Bio-Rad Laboratories, Richmond, CA, USA). Relative cell viability of DADS was expressed as the percentage relative to the control. The following formula was used for the calculation: Cell viability ratio $=1-[(\mathrm{A}$ value of the control $-\mathrm{A}$ value of the experimental samples)/A value of the control] $\mathrm{x} 100 \%$. Half maximal inhibitory concentration $\left(\mathrm{IC}_{50}\right)$ value was calculated by SPSS software (SPSS, Inc., Chicago, IL, USA). Each assay was performed in 5 replicates.

Wound scratch assay. Cell migration ability was conducted by wound scratch assay as previously described (12). In brief, $1 \times 10^{6}$ OE19 cells were cultured in a 6-well plate with medium containing $10 \%$ FBS to make an adherent monolayer. When the cells were cultured to a confluent cell monolayer, a 200- $\mu 1$ Eppendorf tip was used to scratch the cell monolayer to create a uniform wound. The cells were washed three times and cultured in serum-containing RPMI-1640 medium (2\% FBS) with indicated in concentrations of DADS $(2.5,5$ and $10 \mu \mathrm{g} / \mathrm{ml}$, respectively) for $24 \mathrm{~h}$. PBS was used as a control. The wound areas were photographed by phase contrast microscopy at the stages of 0 and $24 \mathrm{~h}$, respectively. The wound area was determined by Image-Pro Plus 6.0 software (Media Cybernetics, Inc., Rockville, MD, USA) in order to calculate the migration distance of the cells. The migration rates were calculated by the following formula: Migration rate $\%=$ original scratch width - new scratch width/original scratch width.

Cell invasion assays. Transwell chamber system (Millipore, Billerica, MA, USA) was performed to examine cancer cell invasion in vitro. Briefly, the upper surface of the membrane was coated with Matrigel (BD Biosciences, Franklin Lakes, NJ, USA). OE19 cells were pretreated with different concentrations of DADS $(2.5,5$ and $10 \mu \mathrm{g} / \mathrm{ml})$. PBS was used as control. OE19 cells $\left(5 \times 10^{4}\right.$ cells $\left./ 200 \mu 1\right)$ of each group were seeded in the upper compartment of the Transwell chamber, and $500 \mu \mathrm{l}$ medium with $20 \%$ FBS was added to the lower compartment of the chamber. After incubation for $24 \mathrm{~h}$, the media were aspirated from inside, and the non-invasive cells on the upper side were removed by a cotton swab. Moreover, the invasive cells located on the lower side of the Matrigelcoated filter were fixed with $4 \%$ paraformaldehyde for $20 \mathrm{~min}$ and stained with $0.1 \%$ crystal violet for $10 \mathrm{~min}$. Images were captured under the optical microscope at x200 magnification. The experiments were conducted in triplicate, and the number of migrated cells in five randomly chosen fields was analyzed for each group. The data analysis was carried out by ImageJ software. Invasion rates were calculated according to the following formula: Invasion $(\%$ of control $)=($ penetration cell number in the experimental group/penetration cell number in the control group) x $100 \%$ (13).

Quantitative real-time polymerase chain reaction. OE19 cells were seeded in 6-well plates. On reaching $80 \%$ confluence, the cells were treated with different concentrations of DADS $(2.5,5$ and $10 \mu \mathrm{g} / \mathrm{ml})$ and harvested for $24 \mathrm{~h}$. PBS was used as the control. Total RNAs were extracted from the cells using 
Table I. Primers for real-time PCR.

\begin{tabular}{lll}
\hline Gene & \multicolumn{1}{c}{ Forward sequence } & \multicolumn{1}{c}{ Reverse sequence } \\
\hline$\beta$-actin & 5'-TGGCACCCAGCACAATGAA-3' & 5'-CTAAGTCATAGTCCGCCTAGAAGCA-3' \\
MMP-2 & 5'-AGTGGATGATGCCTTTGCTC-3' & 5'-GAGTCCGTCCTTACCGTCA-3' \\
MMP-9 & 5'-AGTTTGGTGTCGCGGAGCAC-3' & 5'-TCGTCGAAATGGGCGTCTCCCT-3' \\
TIMP-1 & 5'-TCTGGCATCCTGTTGTTG-3' & 5'-GGTCTGGTTGACTTCTGG-3' \\
TIMP-1 & 5'-TCTGTGACTTCATCGTGCC-3' & 5'-TGACCCAGTCCATCCAGAG-3' \\
u-PA & 5'-ATCTGCCTGCCCTCGATGTATAA-3' & 5'-TTTCAGCTGCTCCGGATAGAGATAG-3' \\
\hline
\end{tabular}

TRIzol reagent according to the manufacturer's instruction (Invitrogen, Carlsbad, CA, USA). The concentrations of RNA were assessed by spectrophotometry at 260 and $280 \mathrm{~nm}$. PCR analysis was performed. The cDNA was obtained by reverse transcription with $1 \mu \mathrm{g}$ total RNA by using PrimeScript ${ }^{\mathrm{TM}} \mathrm{RT}$ Master Mix kit according to the manufacturer's instructions (Takara, Dalian, China). Quantitative real-time polymerase chain reaction was performed using SYBR Premix Ex Taq ${ }^{\mathrm{TM}}$ II Perfect Real-Time kit according to the manufacturer's instructions (Takara). All the reactions were carried out using the ABI System (Bio-Rad Laboratories, Hercules, CA, USA). The cycling conditions were set as follows: $30 \mathrm{sec}$ at $95^{\circ} \mathrm{C}$, followed by 40 cycles of $95^{\circ} \mathrm{C}$ for $5 \mathrm{sec}$ and $60^{\circ} \mathrm{C}$ for $34 \mathrm{sec}$. The samples were run in triplicate in three independent experiments. The amount of each target gene was normalized to $\beta$-actin, and the relative gene expression was calculated by the comparative $C_{T}$ method. All the primer sequences were designed by Premier 5.0 software (Premier Biosoft International, Palo Alto, CA, USA) and synthesized by Takara Bio (Shiga, Japan) (14). The sequences of gene primers are shown in Table I.

Gelatin zymography assay. The effects of DADS on the gelatinolytic activities of MMP-2 and MMP-9 in OE19 cells were examined by gelatin zymography as preiously described (15). OE19 cells were seeded in 10-cm culture dishes. Upon reaching $80 \%$ confluence, the cells were treated with different concentrations of DADS $(2.5,5$ and $10 \mu \mathrm{g} / \mathrm{ml})$ and harvested for $24 \mathrm{~h}$. PBS was used as control. After incubation, the cell conditioned medium was harvested and concentrated at $4^{\circ} \mathrm{C}$. And then, the quantification of the protein concentrations was determined.

The proteolytic enzyme activity of MMP-2 and MMP-9 was measured by gelatin zymography. Briefly, equal amounts of proteins were separated by gelatin substrate gels, which were included on $10 \%$ zymogram gel (Bio-Rad Laboratories) containing $0.1 \%$ gelatin. Electrophoresis was performed at $100 \mathrm{~V}$ for $3 \mathrm{~h}$ at $4^{\circ} \mathrm{C}$. After electrophoresis, the gels were rinsed twice in $2.5 \%$ Triton X-100 for $30 \mathrm{~min}$ to remove SDS. After the washes, the gels were incubated overnight at $37^{\circ} \mathrm{C}$ in $50 \mathrm{mmol} / 1 \mathrm{Tris}-\mathrm{Cl}(\mathrm{pH} \mathrm{7.8)}, 0.2 \mathrm{~mol} / \mathrm{l} \mathrm{NaCl}, 5 \mathrm{mmol} / \mathrm{l}$ $\mathrm{CaCl}_{2}$ and $0.02 \%$ Brij 35. Subsequently, gels were rinsed with distilled water, stained with $0.25 \%$ Coomassie Brilliant Blue for $30 \mathrm{~min}$ and destained with 3-5 washes until the clear bands were visualized. The gelatinolytic activities were quantified by ImageJ software. The experiments were repeated three times. The relative fold changes of protein levels were calculated as ratios between the experimental groups vs. control group.
Preparation of different cell fractions. OE19 cells were seeded in $10-\mathrm{cm}$ culture dishes. Upon reaching $80 \%$ confluence, the cells were treated with different concentrations of DADS (2.5, 5 and $10 \mu \mathrm{g} / \mathrm{ml}$ ) for $24 \mathrm{~h}$. PBS was used as control.

For total protein extraction, the cells $\left(1 \times 10^{6}\right)$ were rinsed twice with ice-cold PBS after incubation, and were lysed in RIPA buffer supplemented with protease inhibitor cocktail and phosphatase inhibitor on ice for $30 \mathrm{~min}$. Cell lysates were centrifuged at $14,000 \mathrm{rpm}$ at $4^{\circ} \mathrm{C}$ for $20 \mathrm{~min}$, and the resulting supernatants were collected (16).

To investigate the cytosolic fraction and nuclear fraction, proteins were prepared as previously described (17). The cells were washed twice with ice-cold PBS, lysed with ice-cold lysis buffer containing $10 \mathrm{mM}$ HEPES, $10 \mathrm{mM} \mathrm{KCl}, 0.1 \mathrm{mM}$ EDTA, $0.1 \mathrm{mM}$ EGTA, $1 \mathrm{mM}$ DTT, $1 \mathrm{mM}$ PMSF and $0.5 \%$ NP-40 with freshly added protease inhibitors for $20 \mathrm{~min}$. The cells were scraped, mixed and centrifuged at $14,000 \mathrm{rpm}$ at $4^{\circ} \mathrm{C}$ for $20 \mathrm{~min}$. The supernatants were saved as the cytosolic fractions at $-80^{\circ} \mathrm{C}$. Moreover, the nuclear pellets were resuspended in ice-cold nuclear extraction buffer containing $20 \mathrm{mM}$ HEPES, $0.4 \mathrm{M} \mathrm{NaCl}, 1 \mathrm{mM}$ EDTA, $1 \mathrm{mM}$ EGTA, $1 \mathrm{mM}$ DTT, $1 \mathrm{mM}$ PMSF and $0.5 \%$ NP-40 with freshly added protease inhibitors on ice for $30 \mathrm{~min}$. After another centrifugation at $12,000 \mathrm{rpm}$ at $4^{\circ} \mathrm{C}$ for $20 \mathrm{~min}$, the supernatant containing the nuclear protein was stored at $-80^{\circ} \mathrm{C}$.

Protein concentrations were determined by the BCA Protein Assay kit (Pierce, Rockford, IL, USA) according to the manufacturer's protocol. Samples were adjusted with lysis buffer and cooked in boiling water for $5 \mathrm{~min}$ for later use.

Western blot assay. Equal amounts of protein extracts $(50 \mu \mathrm{g})$ were loaded and separated by $8-12 \%$ sodium dodecyl sulfate-polyacrylamide gel electrophoresis (SDS-PAGE), and transferred onto polyvinylidene difluoride (PVDF) membranes (Millipore). The membranes were subsequently blocked with 5\% defatted milk in Tris-buffered saline (TBS) containing $0.1 \%$ Tween- 20 at $37^{\circ} \mathrm{C}$ for $4 \mathrm{~h}$. These membranes were probed with specific primary antibodies overnight at $4^{\circ} \mathrm{C}$. After three washes of 10 min each in TBST, the membranes were incubated with appropriate horseradish peroxidase (HRP)conjugated secondary antibodies $(1: 5,000-1: 10,000)$ for $2 \mathrm{~h}$ at room temperature and subsequently washed again.

The peroxidase reaction was visualized with an Enhanced Chemiluminescence Plus kit (Millipore) according to the manufacturer's protocol and exposed by autoradiography to visualize the immunoreactive bands. The densitometric 

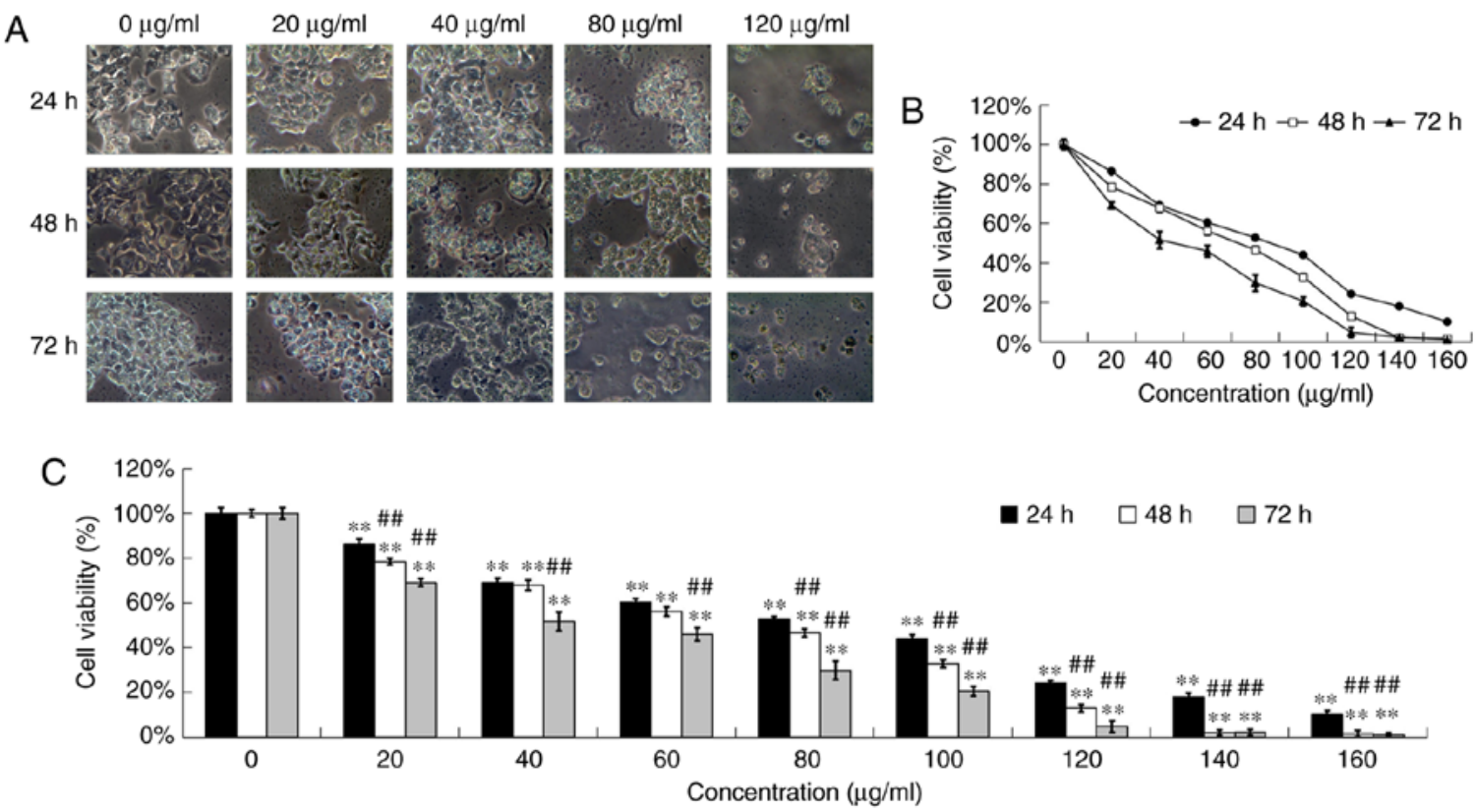

Figure 1. Cytotoxic effects of DADS on OE19 cells. OE19 cells were treated with various concentrations of DADS $(0,20,40,80$ and $120 \mu \mathrm{g} / \mathrm{ml})$ for 24,48 and $72 \mathrm{~h}$. (A) Morphology of OE19 cells treated with various concentrations of DADS for 24, 48 and $72 \mathrm{~h}$ was observed under phase contrast microscopy (magnification, x200). (B and C) OE19 cells were incubated with various concentrations of DADS (0, 20, 40, 60, 80, 100, 120, 140 and $160 \mu \mathrm{g} / \mathrm{ml})$ for 24, 48 and $72 \mathrm{~h}$. Cell viability was detected by MTT assay. The data are represented as the relative absorbance compared with the control. ${ }^{* *} \mathrm{P}<0.01$ compared with the control group; ${ }^{\# \#} \mathrm{P}<0.01$ compared with $24 \mathrm{~h}$ DADS treatment group. DADS, diallyl disulfide.
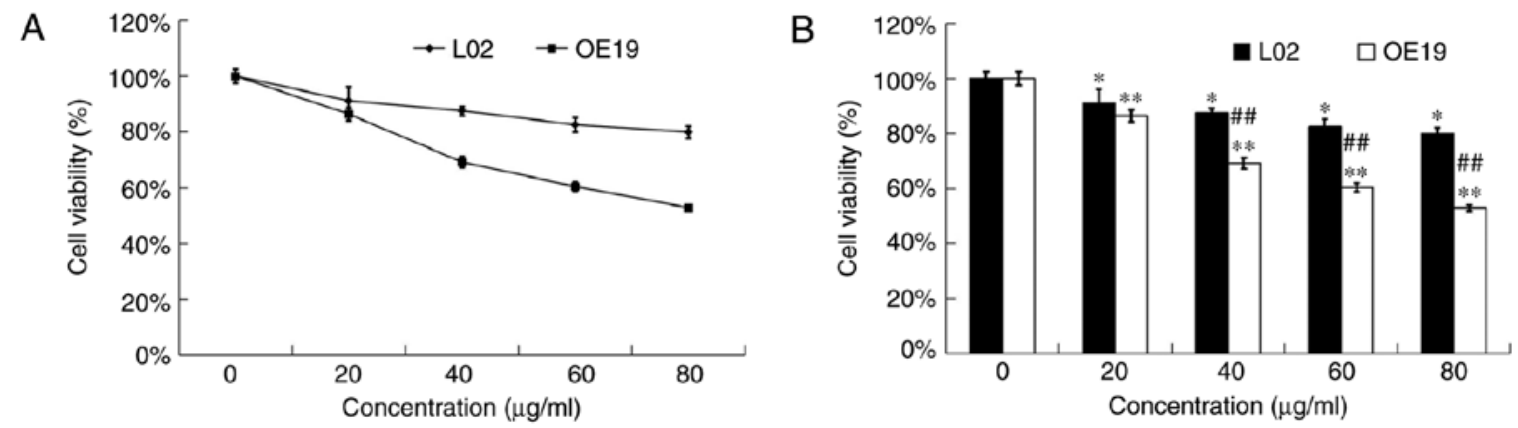

Figure 2. Inhibitory effects of DADS on the viability of OE19 and L02 cells by MTT assay. OE19 and L02 cells were incubated with various concentrations of DADS $(0,20,40,60$ and $80 \mu \mathrm{g} / \mathrm{ml})$ for $24 \mathrm{~h}$, respectively. (A and B) Cell viability was detected by MTT assay. The data are represented as the relative absorbance compared with the control. ${ }^{*} \mathrm{P}<0.05,{ }^{* *} \mathrm{P}<0.01$ compared with the control group, ${ }^{\# \#} \mathrm{P}<0.01$, OE19 group compared with L02 group. DADS, diallyl disulfide.

analysis was performed by ImageJ software. Expression data of the target proteins were normalized by respective $\beta$-actin. The experiments were repeated three times. The relative fold changes of protein levels were calculated as ratios between the treated groups vs. control group (11).

The following primary antibodies were used: anti-MMP-2 antibody (1:500), anti-MMP-9 antibody (1:500), anti-TIMP-1 antibody (1:500), anti-TIMP-2 antibody (1:500), anti-u-PA antibody $(1: 1,000)$, anti-PI3K antibody $(1: 1,000)$, anti-AKT antibody $(1: 1,000)$, anti-p-AKT antibody $(1: 1,000)$, anti-NF- $\kappa \mathrm{B}$ p65 antibody $(1: 1,000)$, anti-I $\kappa \mathrm{B} \alpha$ antibody $(1: 1,000)$, anti-p$\mathrm{I} \kappa \mathrm{B} \alpha$ antibody (1:500) and anti- $\beta$-actin antibody $(1: 1,000)$.

Statistical analysis. Statistical analysis of the data was conducted by the SPSS 17.0 software (SPSS). The results were confirmed by conducting at least three independent experiments, and the quantitative data are presented as the mean \pm SD. The two-tailed Student's t-test was performed for paired samples, and one-way ANOVA or two-factor factorial ANOVA was used to analyze the differences among groups. $\mathrm{P}<0.05$ was highly considered statistically significant and $\mathrm{P}<0.01$ was considered highly statistically significant.

\section{Results}

Cytotoxic effects of DADS on OE19 cells. After incubation with DADS at different concentrations $(0,20,40,80$ and $120 \mu \mathrm{g} / \mathrm{ml}$ ) for 24,48 and $72 \mathrm{~h}$, the OE19 cells were examined by phase contrast microscopy for morphologic characteristics. The control-treated cells showed a typical polygonal and intact appearance, whereas the DADS-treated cells displayed a dose and time-dependent change in cell shape, such as apoptotic bodies, cellular shrinkage, poor adherence and round floating shapes (Fig. 1A). 

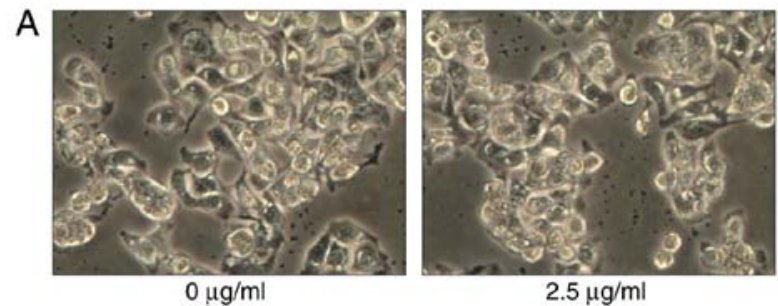
$2.5 \mu \mathrm{g} / \mathrm{m}$

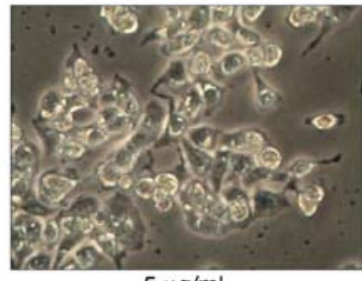

$5 \mu \mathrm{g} / \mathrm{ml}$

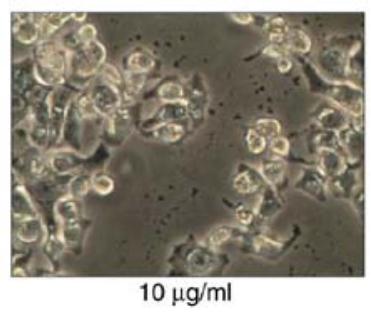

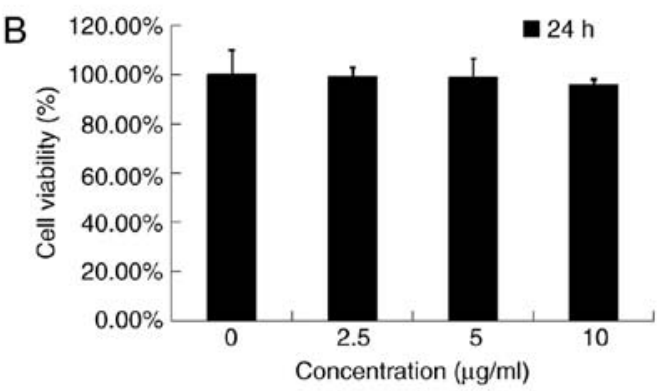

Figure 3. Effects of low-dose DADS on OE19 cells. OE19 cells were treated with low-dose DADS $(0,2.5,5$ and $10 \mu \mathrm{g} / \mathrm{ml})$ for $24 \mathrm{~h}$. (A) Changes in the morphologic characteristics of OE19 cells by low-dose DADS as observed under phase contrast microscope (magnification, x200). (B) The viability of OE19 cells incubated with various concentrations of low-dose DADS for $24 \mathrm{~h}$ was detected by MTT assay. The data are represented as the relative absorbance compared with the control. DADS, diallyl disulfide.

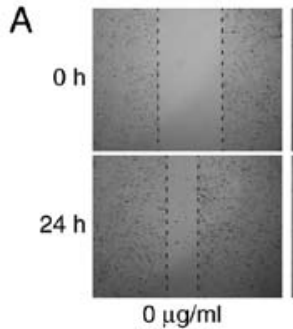

$0 \mu \mathrm{g} / \mathrm{ml}$

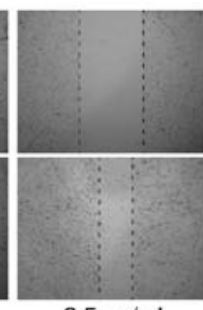

$2.5 \mu \mathrm{g} / \mathrm{ml}$

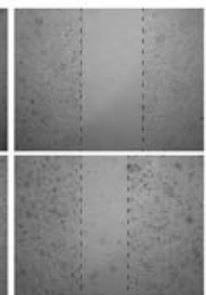

$5 \mu \mathrm{g} / \mathrm{ml}$

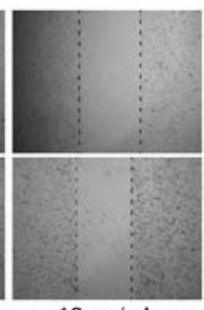

$10 \mu \mathrm{g} / \mathrm{ml}$

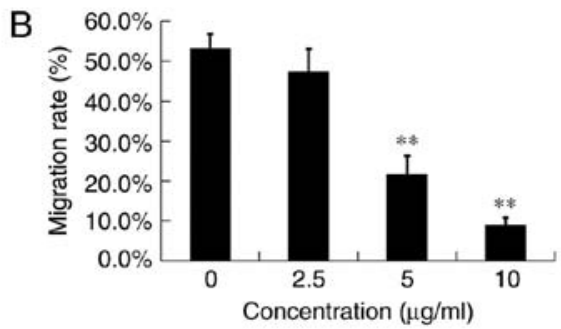

Figure 4. Effects of low-dose DADS on the migration of OE19 cells. OE19 cells were treated with low-dose DADS (0, 2.5, 5 and $10 \mu \mathrm{g} / \mathrm{ml})$ for 24 h. (A) Images of the wounded area of OE19 cells were captured at 0 and $24 \mathrm{~h}$ after low-dose DADS treatment. (B) The migration ability was determined as the percentage of open space covered by migrated cells of the treatment group compared with the control group (magnification, $\mathrm{x} 100$ ). ${ }^{* *} \mathrm{P}<0.01$ compared with the control group. DADS, diallyl disulfide.

MTT assay was used to detect the anti-proliferation effects of DADS at different concentrations $(0,20,40,60,80,100$, 120,140 and $160 \mu \mathrm{g} / \mathrm{ml}$ ) on OE19 cells for 24,48 and $72 \mathrm{~h}$. The results showed that DADS obviously inhibited the viability of OE19 cells in a dose- and time-dependent manner, which indicated that DADS obviously inhibited cell viability at concentrations of $20-160 \mu \mathrm{g} / \mathrm{ml}$ after exposure for 24,48 and $72 \mathrm{~h}(\mathrm{P}<0.01$; Fig. 1B and C). After treatment for 24, 48 and $72 \mathrm{~h}$, the $\mathrm{IC}_{50}$ values of DADS for OE19 cells were estimated to be $90.16,89.58$ and $75.76 \mu \mathrm{g} / \mathrm{ml}$, respectively. In addition, the 72-h treatment group had a significant difference with the 24- and 48-h treatment groups ( $\mathrm{P}<0.01$; Fig. $1 \mathrm{~B}$ and $\mathrm{C})$.

Cytotoxic effects of DADS on healthy hepatocytes L02 cells. MTT assay was used to detect the anti-proliferation effects of DADS at different concentrations $(0,20,40,60$ and $80 \mu \mathrm{g} / \mathrm{ml})$ on OE19 and L02 cells for $24 \mathrm{~h}$. Our data showed that DADS had a much lower cytotoxic effect on L02 healthy hepatocytes than on OE19 carcinoma cells (P<0.01; Fig. 2). Hence, DADS significantly inhibited the viability of type II AEG cells in a dose- and time- dependent manner with less cytotoxicity to healthy hepatocytes in vitro.

Effects of low-dose DADS on OE19 cells. Under a phase contrast microscope, OE19 cells of the control group showed a typical polygonal and intact appearance. Moreover, the lowdose DADS-treated cells displayed no obvious changes in cell morphologic characteristics (Fig. 3A).

MTT assay was used to detect the anti-proliferation effects of low-dose DADS at different concentrations $(0,2.5,5$ and $10 \mu \mathrm{g} / \mathrm{ml}$ ) on OE19 cells for $24 \mathrm{~h}$. Our data showed that DADS at concentrations $<10 \mu \mathrm{g} / \mathrm{ml}$ did not cause cytotoxicity and did not affect the viability after a $24-\mathrm{h}$ treatment $(\mathrm{P}>0.05$; Fig. 3B). To exclude the possibility that the anti-invasive effect of DADS was affected by its cytotoxicity, non-cytotoxic concentrations $(<10 \mu \mathrm{g} / \mathrm{ml}$ for $24 \mathrm{~h})$ were applied in the following experiments.

Effects of DADS on the migration and invasion of OE19 cells. Scratch wound healing assay was used to detect the antimigration effects of DADS at different concentrations $(0,2.5$, 5 and $10 \mu \mathrm{g} / \mathrm{ml}$ ) on OE19 cells for $24 \mathrm{~h}$ (Fig. 4A). Although the scratch wounds were almost the same size in each experimental group at $0 \mathrm{~h}$, the cell migration rates were significantly reduced in the DADS therapy groups compared with the control group in a dose-dependent manner after a $24-\mathrm{h}$ treatment $(\mathrm{P}<0.05$; Fig. 4B). The migration rates of the OE19 cells treated with $0,2.5,5$ and $10 \mu \mathrm{g} / \mathrm{ml}$ DADS were $53.09 \pm 3.75,47.23 \pm 5.82$, $21.60 \pm 4.67$ and $8.90 \pm 1.94 \%$, respectively (Fig. 4B). These results clearly indicated that DADS significantly inhibited the 
A

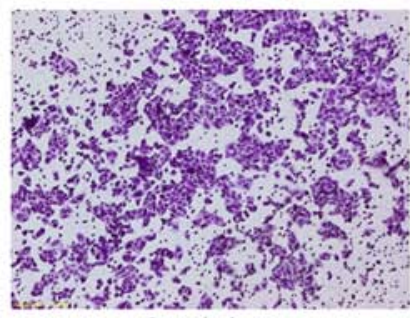

$0 \mu \mathrm{g} / \mathrm{ml}$

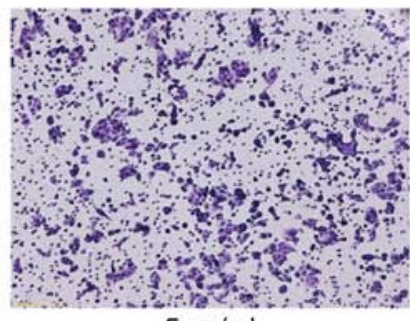

$5 \mu \mathrm{g} / \mathrm{ml}$

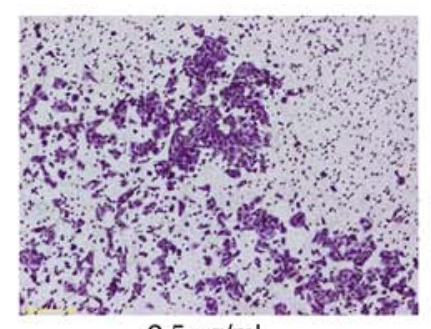

$2.5 \mu \mathrm{g} / \mathrm{ml}$

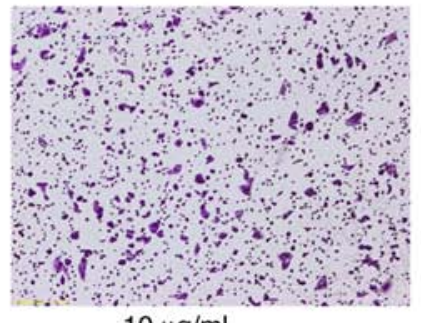

$10 \mu \mathrm{g} / \mathrm{ml}$

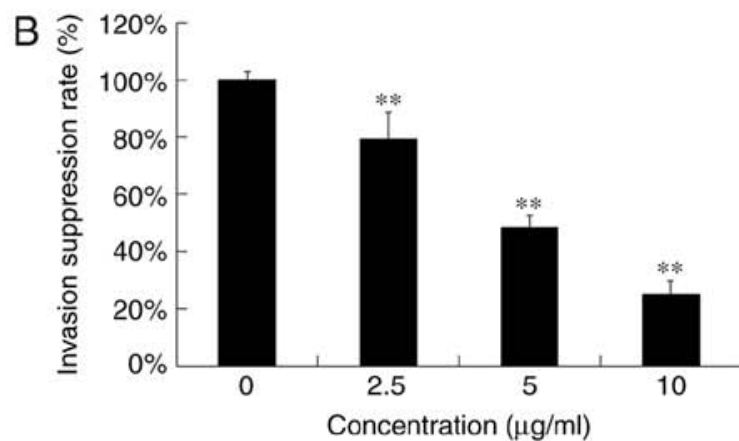

Concentration $(\mu \mathrm{g} / \mathrm{ml})$

Figure 5. Effects of low-dose DADS on the invasion of OE19 cells. OE19 cells were treated with low-dose DADS (0, 2.5, $5 \mathrm{and} 10 \mu \mathrm{g} / \mathrm{ml})$ for $24 \mathrm{~h}$. (A) Images of the invaded OE19 cells were captured at 0 and $24 \mathrm{~h}$ after low-dose DADS treatment (magnification, x100). (B) The invasion rates of OE19 cells pretreated with various concentrations of DADS for $24 \mathrm{~h}$ are expressed as the percentage of the control group. ${ }^{* *} \mathrm{P}<0.01$ compared with the control group. DADS, diallyl disulfide.
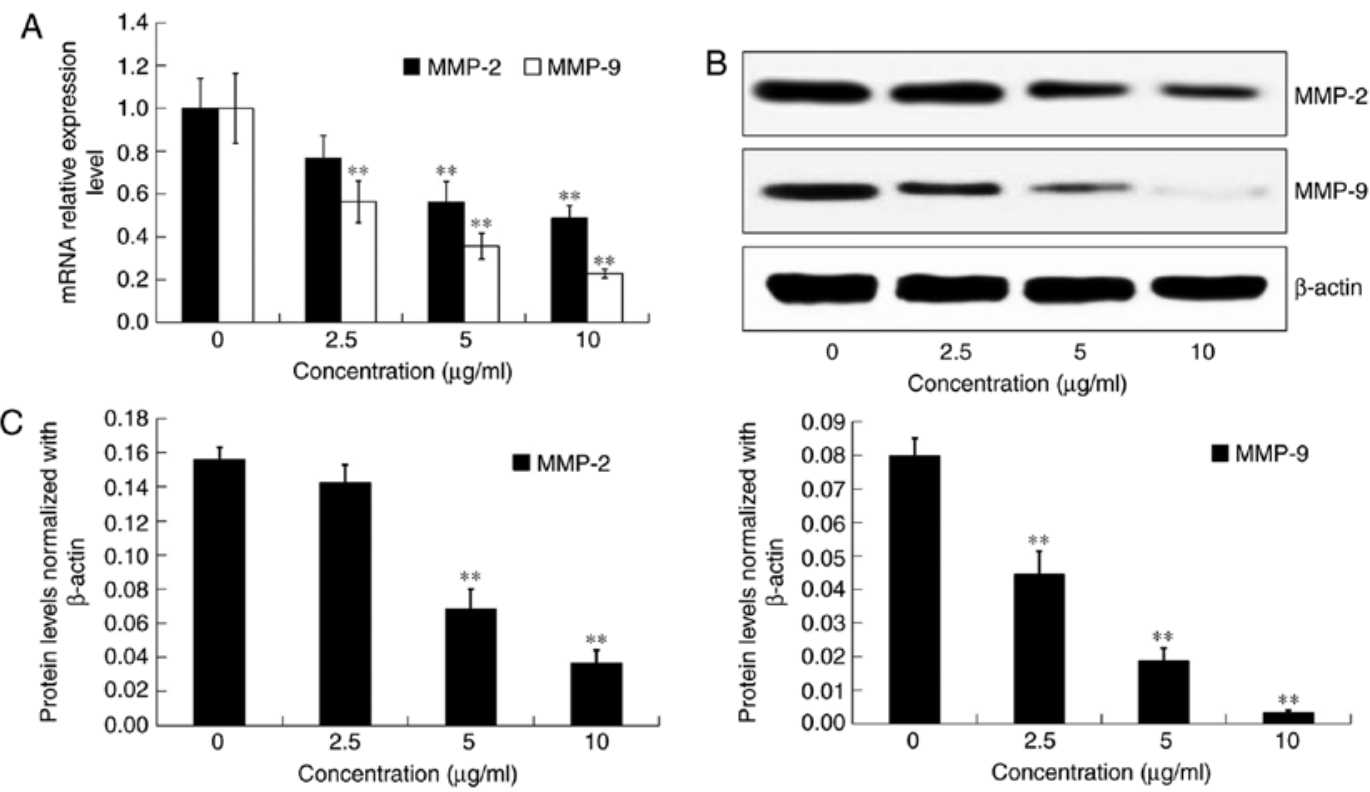

Figure 6. Effects of DADS on the expression of MMP-2 and MMP-9 in OE19 cells. OE19 cells were incubated with low-dose DADS $(0,2.5,5 \mathrm{and} 10 \mu \mathrm{g} / \mathrm{ml})$ for $24 \mathrm{~h}$. (A) The relative mRNA expression of MMP-2 and MMP-9 was assessed by real-time PCR. (B) The protein levels of MMP-2 and MMP-9 were assessed by western blot analysis. Representative western blot of the protein levels of MMP-2 and MMP-9 in OE19 cells treated with DADS is shown. (C) Densitometric analysis of the protein levels of MMP-2 and MMP-9 are shown. ${ }^{* *} \mathrm{P}<0.01$ compared with the control group. DADS, diallyl disulfide.

migration motility of OE19 cells, which was not due to the cytotoxic action.

The cells that invaded through the Matrigel-coated polycarbonate filter in the chamber were analyzed to detect the anti-invasion effects of various concentrations of DADS $(0$, $2.5,5$ and $10 \mu \mathrm{g} / \mathrm{ml}$ ) on OE19 cells (Fig. 5A). Invasion rates of OE19 cells treated with $2.5,5$ and $10 \mu \mathrm{g} / \mathrm{ml}$ of DADS were $79.20 \pm 9.45,48.48 \pm 4.25$ and $24.8 \pm 5.15 \%$, respectively. Compared with the control group, DADS suppressed the invasion of OE19 cells in a dose-dependent manner $(\mathrm{P}<0.05$; Fig. 5B). These results clearly indicated that DADS signifi- cantly inhibited the invasion ability of OE19 cells, which was not due to the cytotoxic action.

Effects of DADS on the expression and activities of MMP-2 and MMP-9 in OE19 cells. After incubation with DADS at different concentrations $(0,2.5,5$ and $10 \mu \mathrm{g} / \mathrm{ml})$ for $24 \mathrm{~h}$, the mRNA expression and protein levels of MMP-2 and MMP-9 in OE19 cells were detected by real-time PCR and western blot analysis, respectively (Fig. 6A and B). Compared with the control group, the transcriptional and translational expression levels of both MMP-2 and MMP-9 were significantly inhibited 

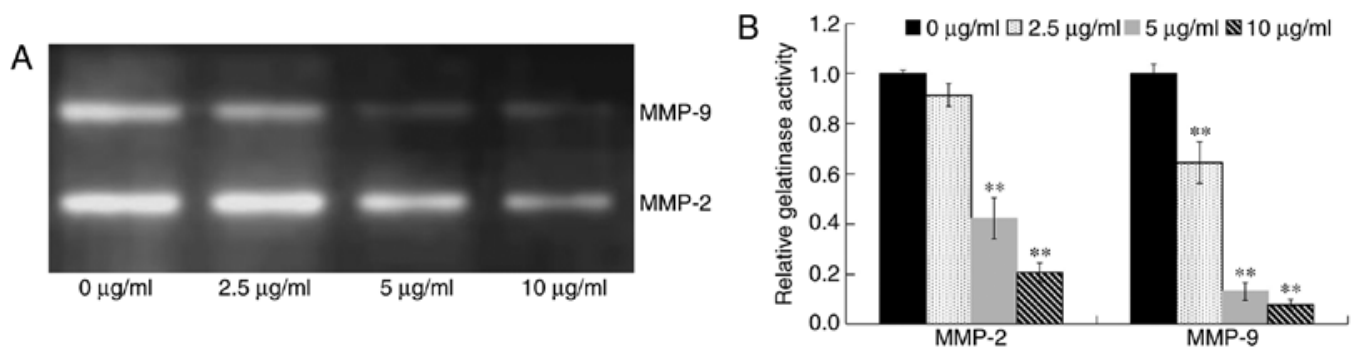

Figure 7. Activities of MMP-2 and MMP-9 were assessed by gelatin zymography assay. (A) Representative western blot of the protein levels of MMP-2 and MMP-9 is shown. (B) Densitometric analysis of the protein levels of MMP-2 and MMP-9 in OE19 cells treated with DADS are shown. ${ }^{* *} \mathrm{P}<0.01$ compared with the control group. DADS, diallyl disulfide.
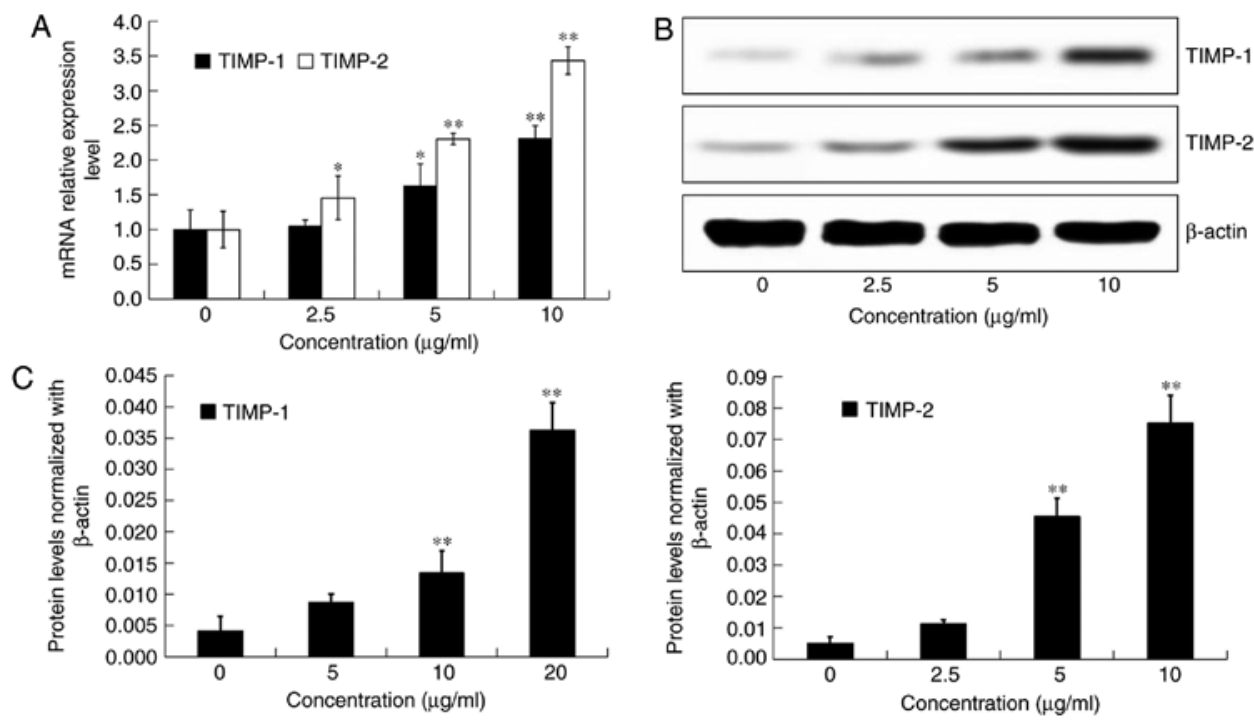

Figure 8. Effects of DADS on the expression of TIMP-1 and TIMP-2 in OE19 cells. OE19 cells were incubated with low-dose DADS $(0,2.5,5 \mathrm{and} 10 \mu \mathrm{g} / \mathrm{ml})$ for $24 \mathrm{~h}$. (A) The mRNA relative expression of TIMP-1 and TIMP-2 was assessed by real-time PCR. (B) The protein levels were assessed by western blot analysis. Representative western blot of the protein expression of TIMP-1 and TIMP-2 in the OE19 cells treated with DADS is shown. (C) Densitometric analysis of the protein levels of TIMP-1 and TIMP-2 are shown. ${ }^{*} \mathrm{P}<0.05,{ }^{* *} \mathrm{P}<0.01$ compared with the control group. DADS, diallyl disulfide.

by DADS treatment in a dose-dependent manner $(\mathrm{P}<0.05$; Fig. 6A and C).

In order to assess the activities of extracellular MMP-2 and MMP-9, OE19 cells were treated with various concentrations of DADS $(0,2.5,5$ and $10 \mu \mathrm{g} / \mathrm{ml})$ for $24 \mathrm{~h}$ in serum-free medium. The conditioned medium was collected, concentrated and assayed for the activities of MMP-2 and MMP-9 by gelatin zymography (Fig. 7A). Compared with the control group, the activities of MMP-2 and MMP-9 in OE19 cells were significantly decreased by DADS treatment in a dose-dependent manner $(\mathrm{P}<0.01$; Fig. 7B), which were connected with the downregulation of their mRNA and protein expression levels. These results indicated that DADS reduced the expression and activities of MMP-2 and MMP-9, and therefore decreased the metastatic abilities of the OE19 cells.

Effects of DADS on the expression of TIMP-1 and TIMP-2 in OE19 cells. After incubation with DADS at different concentrations $(0,2.5,5$ and $10 \mu \mathrm{g} / \mathrm{ml})$ for $24 \mathrm{~h}$, the mRNA expression and protein levels of TIMP-1 and TIMP-2 in OE19 cells were detected by real-time PCR and western blot analysis, respectively (Fig. 8A and $\mathrm{B})$. Compared with the control group, the transcriptional and translational expression levels of both TIMP-1 and TIMP-2 were significantly inhibited by DADS treatment in a dose-dependent manner $(\mathrm{P}<0.05$; Fig. 8A and $\mathrm{C})$. These findings suggested that DADS inhibited cell metastasis by suppressing MMPs through the induction of TIMPs in OE19 cells.

Effects of DADS on the expressions of $u-P A$ in OE19 cells. After incubation with DADS at different concentrations $(0$, $2.5,5$ and $10 \mu \mathrm{g} / \mathrm{ml}$ ) for $24 \mathrm{~h}$, the mRNA expression and protein levels of u-PA in OE19 cells were detected by realtime PCR and western blot analysis, respectively (Fig. 9A and B). Compared with the control group, the transcriptional and translational expression levels of u-PA were significantly inhibited by DADS treatment in a dose-dependent manner $(\mathrm{P}<0.05$; Fig. 9A and $\mathrm{C})$. These results demonstrated that DADS decreased the expression and activities of $\mathrm{u}-\mathrm{PA}$, and therefore decreased the metastatic abilities of the OE19 cells.

Effects of DADS on the expressions of $N F-\kappa B$ pathway in $O E 19$ cells. We performed western blot analyses to investigate whether DADS mediates its anti-metastaticeffects in type II AEG via modulation of the $\mathrm{NF}-\kappa \mathrm{B}$ signaling pathway.

After incubation with DADS at different concentrations ( 0 , $2.5,5$ and $10 \mu \mathrm{g} / \mathrm{ml}$ ) for $24 \mathrm{~h}$, the protein expression of nuclear 

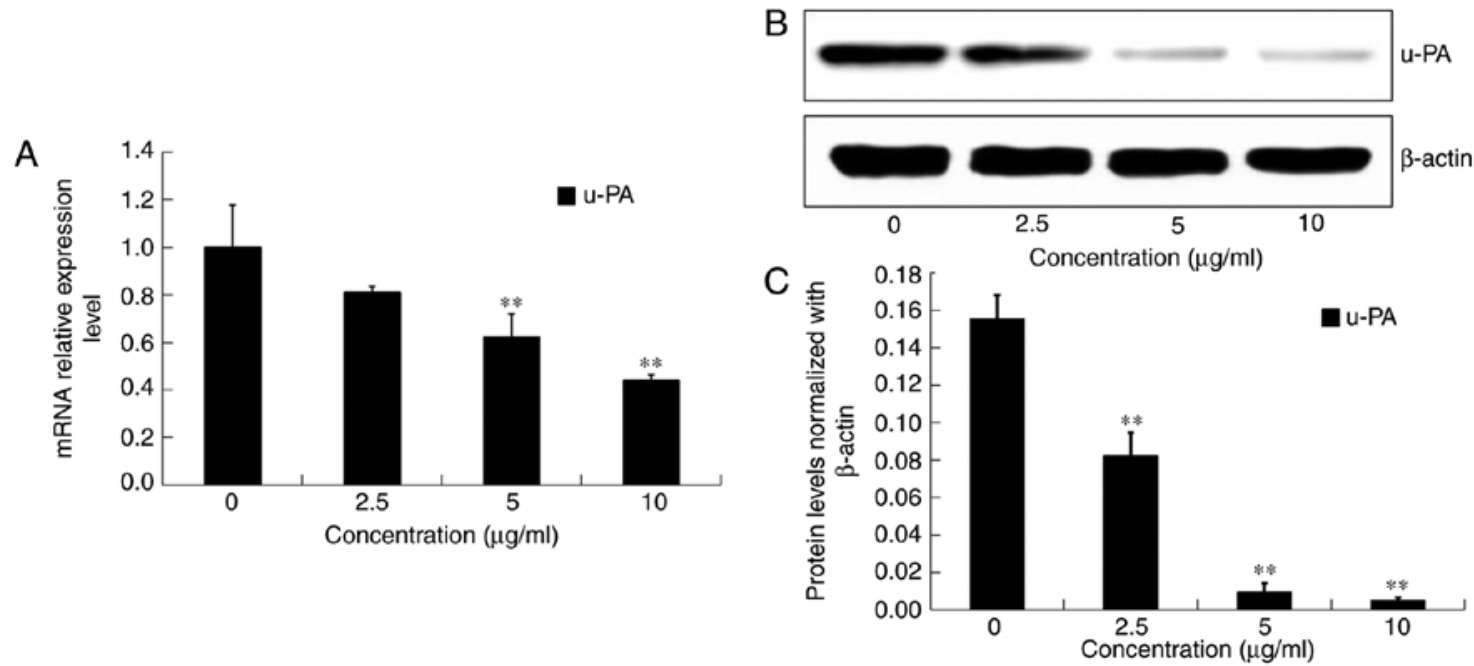

Figure 9. Effects of DADS on the expression of u-PA in OE19 cells. OE19 cells were incubated with different concentrations of DADS $(0,2.5,5$ and $10 \mu \mathrm{g} / \mathrm{ml})$ for $24 \mathrm{~h}$. (A) The relative mRNA expression of u-PA was assessed by real-time PCR. (B) The protein levels were assessed by western blot analysis. Representative western blot of the protein levels of u-PA in OE19 cells treated with DADS is shown. (C) Densitometric analysis of the protein expression of u-PA is shown. ${ }^{* *} \mathrm{P}<0.01$ compared with the control group. DADS, diallyl disulfide.
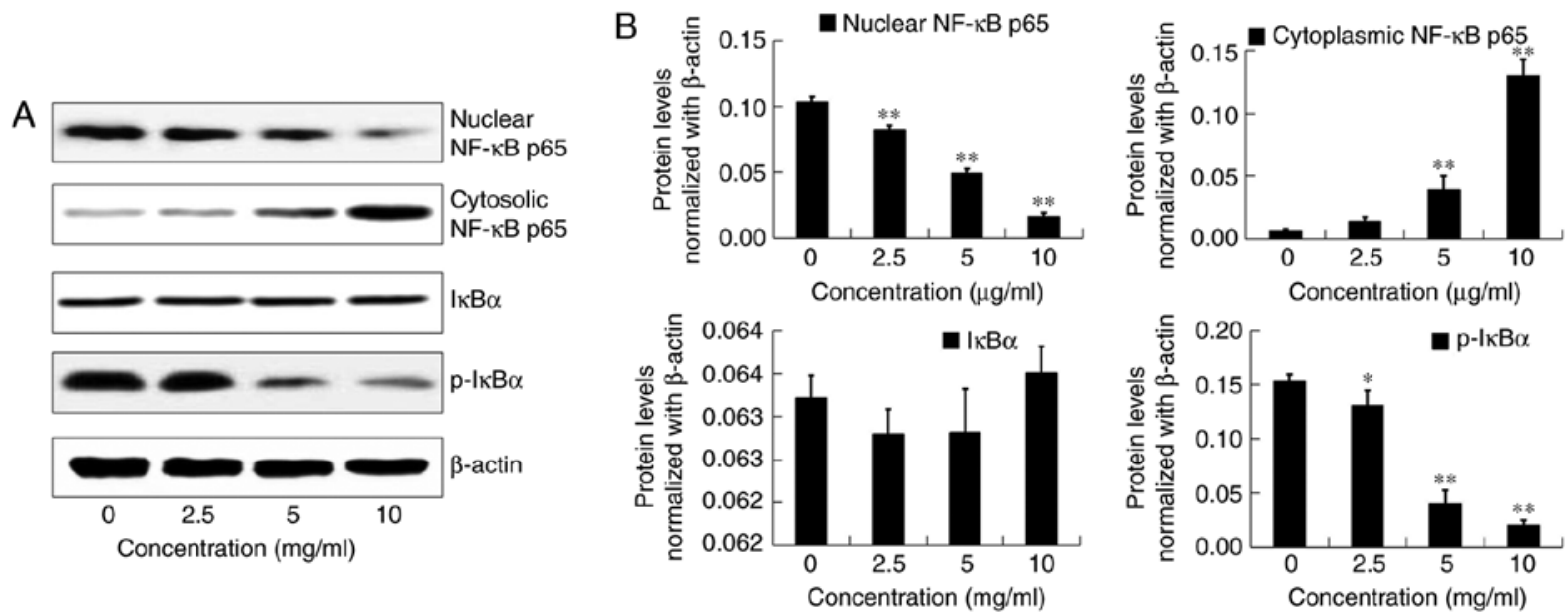

Figure 10. Inhibitory effects of DADS on protein levels of the NF-kB pathway in OE19 cells. OE19 cells were treated with various concentrations of DADS

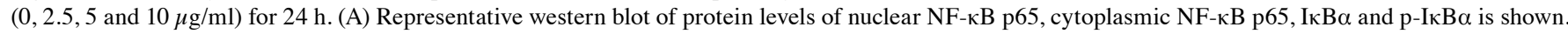

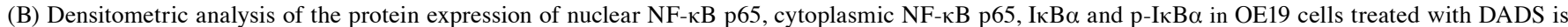
shown. ${ }^{*} \mathrm{P}<0.05,{ }^{* *} \mathrm{P}<0.01$ compared with the control group. DADS, diallyl disulfide.

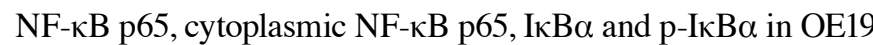
cells was detected by western blot analysis (Fig. 10A). Compared with the control group, DADS significantly inhibited nuclear $\mathrm{NF}-\kappa \mathrm{B}$ p65 and $\mathrm{p}-\mathrm{I} \kappa \mathrm{B} \alpha$ in a dose-dependent manner $(\mathrm{P}<0.05$; Fig. 10B). In addition, 5 and $10 \mu \mathrm{g} / \mathrm{ml}$ DADS significantly increased cytoplasmic protein levels of NF- $\mathrm{BB}$ p65 in OE19 cells $(\mathrm{P}<0.01$; Fig. 10B). However, the expression of total $\mathrm{I} \kappa \mathrm{B} \alpha$ was not affected by DADS in the OE19 cells ( $P>0.05$; Fig. 10B). These results suggest that DADS could decrease the nuclear translocation of NF- $\kappa$ B p 65 and the NF- $\kappa$ B signaling pathway may be involved in the anti-metastatic process induced by DADS.

Effects of DADS on the PI3K/AKT pathway in OE19 cells. To determine whether DADS inhibits the invasion of OE19 cells by modulation of the PI3K/AKT signaling pathway, we tested the effects of DADS on the expression of total PI3K and total AKT, as well as p-PI3K and p-AKT after treatment with different concentrations of DADS $(0,2.5,5$ and $10 \mu \mathrm{g} / \mathrm{ml})$ for $24 \mathrm{~h}$ (Fig. 11A).

Compared with the control group, the total protein expression levels of p-PI3K and p-AKT were significantly decreased by DADS in a dose-dependent manner $(\mathrm{P}<0.01$; Fig. 11B). Moreover, the protein expression levels of total PI3K and AKT were inhibited by 5 and $10 \mu \mathrm{g} / \mathrm{ml}$ DADS treatment $(\mathrm{P}<0.05$; Fig. 11B). These results indicated that the PI3K/AKT signaling pathway plays an important role in the anti-metastatic process induced by DADS in OE19 cells.

\section{Discussion}

The incidence of AEG has evidently increased worldwide. AEG at the early stage can be cured by surgical resection. Moreover, systemic diagnotic techniques and comprehensive treatment for AEG have improved recently. However, these 

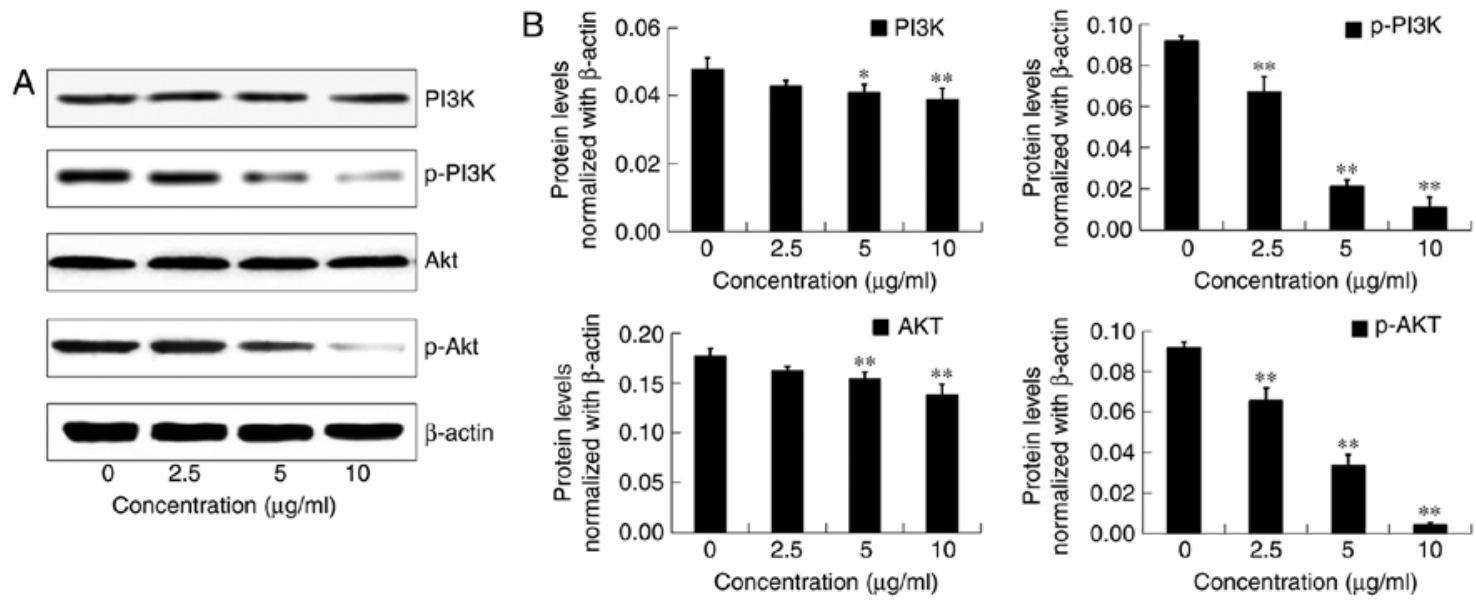

Figure 11. Inhibitory effects of DADS on protein expressions of PI3K/AKT pathway in OE19 cells. OE19 cells were treated with various concentrations of DADS $(0,2.5,5$ and $10 \mu \mathrm{g} / \mathrm{ml})$ for $24 \mathrm{~h}$. (A) Representative western blot of the protein levels of PI3K, p-PI3K, AKT and p-AKT is shown. (B) Densitometric analysis of the protein levels of PI3K, p-PI3K, AKT and p-AKT in OE19 cells treated with DADS is shown. ${ }^{*} \mathrm{P}<0.05,{ }^{* *} \mathrm{P}<0.01$ compared with the control group DADS, diallyl disulfide.

methods are not satisfactory enough for advanced stage AEG patients who have poor prognosis (18). Most of the AEG patients will eventually succumb to the disease. Metastasis is the leading cause of AEG-related mortality. Therefore, it is important to control cancer metastasis in order to obtain a better curative effect for AEG patients (19).

As traditional strategies such as chemotherapy and radiotherapy have strong systemic toxicity, novel therapeutic agents with low toxicity are needed to be investigated for AEG patients. Several studies have documented that DADS may serve as a potential anti-metastatic agent in various carcinomas $(6,9-10,20-23)$. In the present study, we demonstrated that different concentrations of DADS significantly altered the morphologic characters and reduced cell viability of OE19 cells after treatment for 24,48 and $72 \mathrm{~h}$ in a doseand time-dependent manner with less cytotoxicity to L02 healthy hepatocytes in vitro (Figs. 1 and 2). However, DADS $<10 \mu \mathrm{g} / \mathrm{ml}$ did not cause cytotoxicity and affect the viability after 24-h treatment (Fig. 3). Therefore, we used the non-cytotoxic concentrations of DADS (0, 2.5, 5 and $10 \mu \mathrm{g} / \mathrm{ml}$ for $24 \mathrm{~h})$ to test the anti-metastatic effects in OE19 cells. The wound scratch assay was used to assess the motility, and the Matrigel invasion assay was used to assess the ability to penetrate the ECM, respectively, in the present study. Our data provided evidence that DADS at non-toxic doses could significantly inhibit the migratory and invasive abilities of OE19 cells in a dose-dependent manner (Figs. 4 and 5). These results implied that anti-metastatic potential by DADS in OE19 cells was not due to its cytotoxic effects, which is consistent with previous research findings (21-23).

DADS facilitates cancer progression in vitro and in vivo through complicated mechanisms (6,9-10,20-23). However, little is known about the molecular mechanisms of the inhibition of invasion and metastasis of AEG by DADS treatment. To elucidate the underlying mechanisms responsible for the anti-metastatic properties of DADS in type II AEG OE19 cells, more studies are required for a better understanding.

The adhesive ability of cells and ECM degradation are fundamental to tumor metastasis (24). The urokinase plasmin- ogen activator (u-PA) and matrix metalloproteinases (MMPs) are proteolytic enzymes secreted by invasive cancer cells (25). They are crucial for ECM degradation, tumor cell metastasis, as well as a poor survival in various malignant tumors (26). The activity of u-PA may be the most sensitive factor reflecting cancer metastasis in this plasminogen activation system (27). MMPs including MMP-2 (gelatinase A, $72 \mathrm{kDa}$ ) and MMP-9 (gelatinase B, $92 \mathrm{kDa}$ ) belong to zinc-containing endopeptidase family (28). Moreover, the activities of most MMPs are regulated by their natural endogenous inhibitors, such as tissue inhibitors of metalloproteinase (TIMPs). TIMPs can form 1:1 stoichiometric complexes with MMPs to affect their biological activities (29). DADS restrains migration and invasion of gastric cancer AGS cells via downregulation of the expression and activity of MMPs (30). However, the regulation of MMPs, TIMPs and u-PA in AEG by DADS treatment has not been identified. The present study indicated that treatment with DADS at 5 and $10 \mu \mathrm{g} / \mathrm{ml}$ for $24 \mathrm{~h}$ notably inhibited the activities as well as mRNA expressions and protein levels of MMP-2, MMP-9 and u-PA in OE19 cells (Figs. 6, 7 and 9). In addition, the transcriptional and translational levels of both TIMP-1 and TIMP-2 were significantly increased by DADS at 5 and $10 \mu \mathrm{g} / \mathrm{ml}$ for $24 \mathrm{~h}$ (Fig. 8). Therefore, the inhibitory effect of DADS on MMP-2, MMP-9 and u-PA, as well as the induction ability of DADS on TIMP-1 and TIMP-2 might be responsible for the suppressive effect of DADS on migration and invasion of OE19 cells.

The promoters of $\mathrm{u}$-PA and MMPs are highly conserved and contain multiple functional elements including NF- $\kappa B$. Nuclear factor $\kappa \mathrm{B}(\mathrm{NF}-\kappa \mathrm{B})$, a transcription factor, regulates the expression of numerous genes and plays an important role in the hallmarks of cancer development (31). While being in the cytoplasm, NF- $\mathrm{kB}$ is kept in an inactive form by the inhibitory protein called inhibitor of $\kappa \mathrm{B}(\mathrm{I} \kappa \mathrm{B})$. Degradation of $\mathrm{I} \kappa \mathrm{B}$ leads to the activation of the pathway, resulting in the nuclear translocation of the NF- $\kappa B$ complexes (32). In the nucleus, activated NF- $\mathrm{KB}$ binds to the specific DNA sequence called response element in the promoter region of a number of target genes including cytokines, chemokines, adhesion molecules as 
well as angiogenic factors and key enzymes, and subsequently regulates tumor initiation and progression (33). The promotion of NF- $\kappa$ B pathway increases the metastatic activity of cancer cells by upregulating u-PA and MMPs (34). Thus, blocking the NF- $\mathrm{BB}$ pathway is likely to be associated with the downregulation of $\mathrm{u}-\mathrm{PA}$ and MMPs. It is a promising strategy for the suppression of tumor initiation and the inhibition of tumor metastasis (35). Although the correlation between cancer invasion and NF- $\kappa \mathrm{B}$ activity has been determined, the molecular mechanisms of DADS on $\mathrm{NF}-\kappa \mathrm{B}$ pathway are still poorly understood. In the present study, we demonstrated that DADS at 5 and $10 \mu \mathrm{g} / \mathrm{ml}$ notably elevated the cytoplasmic NF- $\kappa \mathrm{B}$ (P65) protein level and abolished nuclear NF- $\mathrm{B}$ (P65) protein levels, and significantly decreased $\mathrm{p}-\mathrm{I} \kappa \mathrm{B} \alpha$ protein levels without affecting total $\mathrm{I} \kappa \mathrm{B} \alpha$ expression (Fig. 10). The data suggested that the anti-metastatic mechanism of DADS was at least in part associated with the suppression of the $\mathrm{NF}-\kappa \mathrm{B}$ pathway and the translocation of NF- $\kappa \mathrm{B}$ p65 to the nucleus in OE19 cells, which was associated with the downregulation of MMP-2, MMP-9 and u-PA.

$\mathrm{NF}-\kappa \mathrm{B}$ is the downstream target of the PI3K/AKT signaling pathway. The PI3K/AKT pathway plays a central role in regulating the expression of MMPs and u-PA by transcriptional factors including NF- $\kappa \mathrm{B}$ (36). Activation of PI3K generates second messenger PIP3, which promotes the colocalization and phosphorylation of AKT Ser308 at the membrane in turn (37). PI3K/AKT signaling pathway is deregulated in various cancers, which plays a key role in cell survival and proliferation, glucose metabolism, apoptosis, adhesion and metastasis (38). DADS was found to cause a significant reduction in the invasion of SGC-7901 cells by upregulating miR-34a, via the inhibition of the PI3K/AKT signaling pathway (39). Our data are consistent with this concept. The present study demonstrated that the profound inhibitory effect of the migration and invasion by DADS was induced by significantly inhibiting phosphorylation of PI3K and AKT in OE19 cells (Fig. 11). Therefore, the blocking of the PI3K/AKT signaling pathway may provide potential targets for suppressing the metastasis of type II AEG cells.

To the best of our knowledge, the present study presented the first evidence that DADS e inhibited cell viability in human type II AEG cells with little effect on healthy hepatocytes. Moreover, we provided the evidence that low-dose DADS without an obvious cytotoxic effect significantly reduced the migration and invasion of OE19 cells in vitro. Herein, our findings also showed that DADS regulated invasion and metastasis of OE19 cells via multiple networks involving various signaling contexts. DADS significantly inhibited u-PA, MMP-2 and MMP-9 expression by upregulating TIMP-1 and TIMP-2 expression. These results were probably associated with the inhibition of invasiveness by suppressing PI3K/ AKT and NF- $\kappa \mathrm{B}$ signaling pathways in OE19 cells. Overall, the cytotoxic effects and the anti-invasive effects of DADS on OE19 cells seemed to be independently exerted. Our data elicited a new experimental basis for the clinical application of DADS. Most importantly, these findings suggest that DADS may be used as a novel promising anti-metastatic agent with few side-effects for the treatment of metastatic type II AEG patients to improve long-term survival rates at last in the near future.

\section{Acknowledgments}

The present study was supported by the Fund for the Important Clinic Project of the Chinese Ministry of Health (no. 2007353), the National Natural Science Foundation of China (no. 81274136) and the Science and Technology Program of Shaanxi Province (no. 2011K13-02-05). This study was supported by the Research Center of Second Affiliated Hospital of Xi'an Jiaotong University. The authors are grateful for Professor Zongfang Li and Professor Ke Li for their excellent technical assistance.

\section{References}

1. Liao LM, Vaughan TL, Corley DA, Cook MB, Casson AG, Kamangar F, Abnet CC, Risch HA, Giffen C, Freedman ND, et al: Nonsteroidal anti-inflammatory drug use reduces risk of adenocarcinomas of the esophagus and esophagogastric junction in a pooled analysis. Gastroenterology 142: 442-452.e5, quiz e22-e23, 2012.

2. Zhang H, Wang W, Diao D, Cheng Y, Song Y, Zhu K and Dang C: Ratio of metastatic to examined lymph nodes, a helpful staging system and independent prognostic factor of esophagogastric junction cancer. PLoS One 8: e73238, 2013.

3. Guo Q, Jin Z, Yuan Y, Liu R, Xu T, Wei H, Xu X, He S, Chen S, Shi Z, et al: New mechanisms of tumor-associated macrophages on promoting tumor progression: Recent research advances and potential targets for tumor immunotherapy. J Immunol Res 2016: 9720912, 2016.

4. Matés JM, Segura JA, Alonso FJ and Márquez J: Anticancer antioxidant regulatory functions of phytochemicals. Curr Med Chem 18: 2315-2338, 2011.

5. Eswar K, Venkateshbabu N, Rajeswari K and Kandaswamy D: Dentinal tubule disinfection with $2 \%$ chlorhexidine, garlic extract, and calcium hydroxide against Enterococcus faecalis by using real-time polymerase chain reaction: In vitro study. J Conserv Dent 16: 194-198, 2013.

6. Zhou Y, Su J, Shi L, Liao Q and Su Q: DADS downregulates the Rac1-ROCK1/PAK1-LIMK1-ADF/cofilin signaling pathway, inhibiting cell migration and invasion. Oncol Rep 29: 605-612, 2013.

7. Yi L and Su Q: Molecular mechanisms for the anti-cancer effects of diallyl disulfide. Food Chem Toxicol 57: 362-370, 2013.

8. Alam M, Zubair S, Farazuddin M, Ahmad E, Khan A, Zia Q, Malik A and Mohammad O: Development, characterization and efficacy of niosomal diallyl disulfide in treatment of disseminated murine candidiasis. Nanomedicine (Lond) 9: 247-256, 2013.

9. Ling H, He J, Tan H, Yi L, Liu F, Ji X, Wu Y, Hu H, Zeng X, Ai $\mathrm{X}$, et al: Identification of potential targets for differentiation in human leukemia cells induced by diallyl disulfide. Int J Oncol 50: 697-707, 2017.

10. Yi L, Shan J, Chen X, Li G, Li L, Tan H and Su Q: Involvement of calreticulin in cell proliferation, invasion and differentiation in diallyl disulfide-treated HL-60 cells. Oncol Lett 12: 1861-1867, 2016.

11. Yin X, Zhang R, Feng C, Zhang J, Liu D, Xu K, Wang X, Zhang S, Li Z, Liu X and Ma H: Diallyl disulfide induces G2/M arrest and provokes apoptosis through p53/p21 and MEK-ERK pathways on human squamous cell esophageal carcinoma. Oncol Rep 32: 1748-1756, 2014.

12. Bao B, Ali S, Banerjee S, Wang Z, Logna F, Azmi AS, Kong D, Ahmad A, Li Y, Padhye S and Sarkar FH: Curcumin analogue CDF inhibits pancreatic tumor growth by switching on suppressor microRNAs and attenuating EZH2 expression. Cancer Res. Am J Cancer Res 3: 465-477, 2013.

13. Han X, Yan DM, Zhao XF, Matsuura H, Ding WG, Li P, Jiang S, Du BR, Du PG and Zhu X: GHGKHKNK octapeptide (P-5m) inhibits metastasis of HCCLM3 cell lines via regulation of MMP-2 expression in in vitro and in vivo studies. Molecules 17: 1357-1372, 2012.

14. Yin X, Zhang J, Li X, Liu D, Feng C, Liang R, Zhuang K, Cai C, Xue X, Jing F, et al: DADS suppresses human esophageal xenograft tumors through RAF/MEK/ERK and mitochondriadependent pathways. Int J Mol Sci 15: 12422-12441, 2014. 
15. Leow PC, Tian Q, Ong ZY, Yang Z and Ee PL: Antitumor activity of natural compounds, curcumin and PKF118-310, as Wnt/ $\beta$-catenin antagonists against human osteosarcoma cells. Invest New Drugs 28: 766-782, 2010.

16. El Hasasna H, Saleh A, Al Samri H, Athamneh K, Attoub S, Arafat K, Benhalilou N, Alyan S, Viallet J, Al Dhaheri Y, et al: Rhus coriaria suppresses angiogenesis, metastasis and tumor growth of breast cancer through inhibition of STAT3, NF- $\mathrm{BB}$ and nitric oxide pathways. Sci Rep 6: 21144, 2016.

17. Pal HC, Sharma S, Strickland LR, Katiyar SK, Ballestas ME, Athar M, Elmets CA and Afaq F: Fisetin inhibits human melanoma cell invasion through promotion of mesenchymal to epithelial transition and by targeting MAPK and NF- $\kappa \mathrm{B}$ signaling pathways. PLoS One 9: e86338, 2014.

18. Schulze B, Bergis D, Balermpas P, Trojan J, Woeste G, Bechstein WO, Rödel C and Weiss C: Neoadjuvant chemoradiation versus perioperative chemotherapy followed by surgery in resectable adenocarcinomas of the esophagogastric junction: A retrospective single center analysis. Oncol Lett 7: 534-540, 2014.

19. Hanahan D and Weinberg RA: Hallmarks of cancer: The next generation. Cell 144: 646-674, 2011

20. Huang J, Yang B, Xiang T, Peng W, Qiu Z, Wan J, Zhang L, Li H, $\mathrm{Li} \mathrm{H}$ and Ren G: Diallyl disulfide inhibits growth and metastatic potential of human triple-negative breast cancer cells through inactivation of the $\beta$-catenin signaling pathway. Mol Nutr Food Res 59: 1063-1075, 2015 .

21. Su B, Su J, Zeng Y, Liu F, Xia H, Ma YH, Zhou ZG, Zhang S, Yang BM, Wu YH, et al: Diallyl disulfide suppresses epithelial-mesenchymal transition, invasion and proliferation by downregulation of LIMK1 in gastric cancer. Oncotarget 7 : 10498-10512, 2016.

22. Lai KC, Hsu SC, Kuo CL, Yang JS, Ma CY, Lu HF, Tang NY, Hsia TC, Ho HC and Chung JG: Diallyl sulfide, diallyl disulfide, and diallyl trisulfide inhibit migration and invasion in human colon cancer colo 205 cells through the inhibition of matrix metalloproteinase-2, -7, and -9 expressions. Environ Toxicol 28: 479-488, 2013

23. Xiao X, Chen B, Liu X, Liu P, Zheng G, Ye F, Tang H and Xie X: Diallyl disulfide suppresses SRC/Ras/ERK signaling-mediated proliferation and metastasis in human breast cancer by up-regulating miR-34a. PLoS One 9: e112720, 2014.

24. Suzuki O, Abe M, Hashimoto Y. Suzuki O, Abe M and Hashimoto Y: Sialylation and glycosylation modulate cell adhesion and invasion to extracellular matrix in human malignant lymphoma: Dependency on integrin and the Rho GTPase family. Int J Oncol Dec 47: 2091-2099, 2015

25. Kantelhardt EJ, Vetter M, Schmidt M, Veyret C, Augustin D, Hanf V, Meisner C, Paepke D, Schmitt M, Sweep F, et al: Prospective evaluation of prognostic factors uPA/PAI-1 in node-negative breast cancer: Phase III NNBC3-Europe trial (AGO, GBG, EORTC-PBG) comparing $6 \times \mathrm{FEC}$ versus $3 \times$ FEC/3×Docetaxel. BMC Cancer 11: 140, 2011.

26. Zhao XL, Sun T, Che N, Sun D, Zhao N, Dong XY, Gu Q, Yao Z and Sun BC: Promotion of hepatocellular carcinoma metastasis through matrix metalloproteinase activation by epithelial-mesenchymal transition regulator Twist1. J Cell Mol Med 15: 691-700, 2011.
27. Kim EY, Do SI, Hyun K, Park YL, Kim DH, Chae SW, Sohn JH and Park $\mathrm{CH}$ : High expression of urokinase-type plasminogen activator is associated with lymph node metastasis of invasive ductal carcinoma of the breast. J Breast Cancer 19: 156-162, 2016.

28. Zhou G, Peng F, Zhong Y, Chen Y, Tang M and Li D: Rhein suppresses matrix metalloproteinase production by regulating the Rac1/ROS/MAPK/AP-1 pathway in human ovarian carcinoma cells. Int J Oncol 50: 933-941, 2017.

29. Kim YS, Kim SH, Kang JG and Ko JH: Expression level and glycan dynamics determine the net effects of TIMP-1 on cancer progression. BMB Rep 45: 623-628, 2012.

30. Park HS, Kim GY, Choi IW, Kim ND, Hwang HJ, Choi YW and Choi YH: Inhibition of matrix metalloproteinase activities and tightening of tight junctions by diallyl disulfide in AGS human gastric carcinoma cells. J Food Sci 76: T105-T111, 2011.

31. Shaked H, Hofseth LJ, Chumanevich A, Chumanevich AA, Wang J, Wang Y, Taniguchi K, Guma M, Shenouda S, Clevers H, et al: Chronic epithelial NF- $\mathrm{BB}$ activation accelerates APC loss and intestinal tumor initiation through iNOS up-regulation. Proc Natl Acad Sci USA 109: 14007-14012, 2012.

32. Guan Z, Ding C, Du Y, Zhang K, Zhu JN, Zhang T, He D, Xu S, Wang $X$ and Fan J: HAF drives the switch of HIF-1 $\alpha$ to HIF-2 $\alpha$ by activating the NF- $\kappa \mathrm{B}$ pathway, leading to malignant behavior of T24 bladder cancer cells. Int J Oncol 44: 393-402, 2014.

33. Simko V, Takacova M, Debreova M, Laposova K, OndriskovaPanisova E, Pastorekova S, Csaderova L and Pastorek J: Dexamethasone downregulates expression of carbonic anhydrase IX via HIF-1 $\alpha$ and NF-кB-dependent mechanisms. Int J Oncol 49: 1277-1288, 2016.

34. Li X, Xu B, Moran MS, Zhao Y, Su P, Haffty BG, Shao C and Yang Q: 53BP1 functions as a tumor suppressor in breast cancer via the inhibition of NF- $\kappa$ B through miR-146a. Carcinogenesis 33: 2593-2600, 2012

35. Zong H, Wang F, Fan QX and Wang LX: Curcumin inhibits metastatic progression of breast cancer cell through suppression of urokinase-type plasminogen activator by NF-kappa B signaling pathways. Mol Biol Rep 39: 4803-4808, 2012.

36. Freise C, Ruehl M, Erben U, Neumann U, Seehofer D, Kim KY, Trowitzsch-Kienast W, Stroh T, Zeitz M and Somasundaram R: A hepatoprotective Lindera obtusiloba extract suppresses growth and attenuates insulin like growth factor-1 receptor signaling and NF-kappaB activity in human liver cancer cell lines. BMC Complement Altern Med 11: 39, 2011

37. Tian F, Ding D and Li D: Fangchinoline targets PI3K and suppresses PI3K/AKT signaling pathway in SGC7901 cells. Int J Oncol 46: 2355-2363, 2015.

38. Miao $X$ and Zhao Y: ST6GalNAcII mediates tumor invasion through $\mathrm{PI} 3 \mathrm{~K} / \mathrm{Akt} / \mathrm{NF}-\mathrm{\kappa B}$ signaling pathway in follicular thyroid carcinoma. Oncol Rep 35: 2131-2140, 2016.

39. Wang G, Liu G, Ye Y, Fu Y and Zhang X: Upregulation of miR-34a by diallyl disulfide suppresses invasion and induces apoptosis in SGC-7901 cells through inhibition of the PI3K/Akt signaling pathway. Oncol Lett 11: 2661-2667, 2016. 